\title{
Етиология на рецидивиращата респираторна папиломатоза
}

\author{
Спиридон Тодоров \\ УМБАЛ "Царица Йоанна - ИСУЛ" ЕАД - София
}

\begin{abstract}
:
Recurrent Respiratory Papillomatosys (RRP) is a relatively rare disease, which is characterized by growth of papillomas in the airways. Most often the disease is in the larynx, but rarely there are cases when it spreads to the trachea, bronchi and the lungs, also the oropharunx and the esophagus. The disease is found in both adults and children. The age at which the RRP appears may be vital for the way that the disease develops. In older patients, males become sick more often than females. The papillomas are usually single, they rarely recur, but they have a tendency to turn malignant. In children both genders are equally affected. The papillomas are multiple and have the tendency to recur. The papillomas are the most common benign tumor of the larynx in childhood and they are the second most usual cause for the rough voice among the children. The disease is caused by the Human papillomavirus (HPV).
\end{abstract}

\section{Резюме:}

Рецидивиращата респираторна папиломатоза (РРП) е относително рядко заболяване, което се характеризира с разрастване на папиломи по лигавицата на дихателните пътища. Най-често засегнат е ларинксът, но не са редки случаите на обхващане и на трахеята, бронхите и белодробния паренхим, както и лигавицата на орофаринкса и хранопровода. Заболяването засяга както деца, така и възрастни, като възрастта на поява има значение за някои особености в клиничното му протичане. При възрастните пациенти мъжете боледуват по-често от жените, папиломите най-често са единични, рядко рецидивират, но имат склонност към малигнизация. При децата еднакво засегнати са и двата пола, папиломите са множествени и проявяват голяма склонност към рецидиви. Папиломите са най-честият доброкачествен тумор на ларинкса в детската възраст и са втората по честота причина за дрезгавия глас у децата. Заболяването се причинява от човешкия папиломен вирус Human papillomavirus (HPV).
$\mathrm{P}$ ецидивиращата респираторна папиломатоза е заболяване с вирусна етиология, причинено от Human papillomavirus (HPV). Папиломните вируси са открити от Richard Shope (1933 год.) $)^{1}$, но до 70-те години на 20. век са били обсъждани единствено като причинители на доброкачествените кожни брадавици при бозайниците и човека. За дъльг период от време папиломните вируси бяха групирани заедно с полиомния вирус и маймунския вакуолизиращ вирус в семейството Papovaviridae. През 2000 година Международният комитет по таксономия на вирусите (ICTV) отдели тези вируси в самостоятелно семейство Papillomaviridae.

Това са широка гама вируси, които инфектират гръбначните от птиците до човека, като причиняват доброкачествени или злокачествени лезии. В зависимост от техния естествен приемник те се разделят на говежди, миши и човешки вид, като тази видова специфичност е абсолютна.

HPV представлява безкапсулен вирус с икозохедрална симетрия от 72 капсомери, които обхващат един геном, съдържащ двойноверижна циркулярна ДНК, съставена от 7900 чифта нуклеотиди (фиг. 1) 


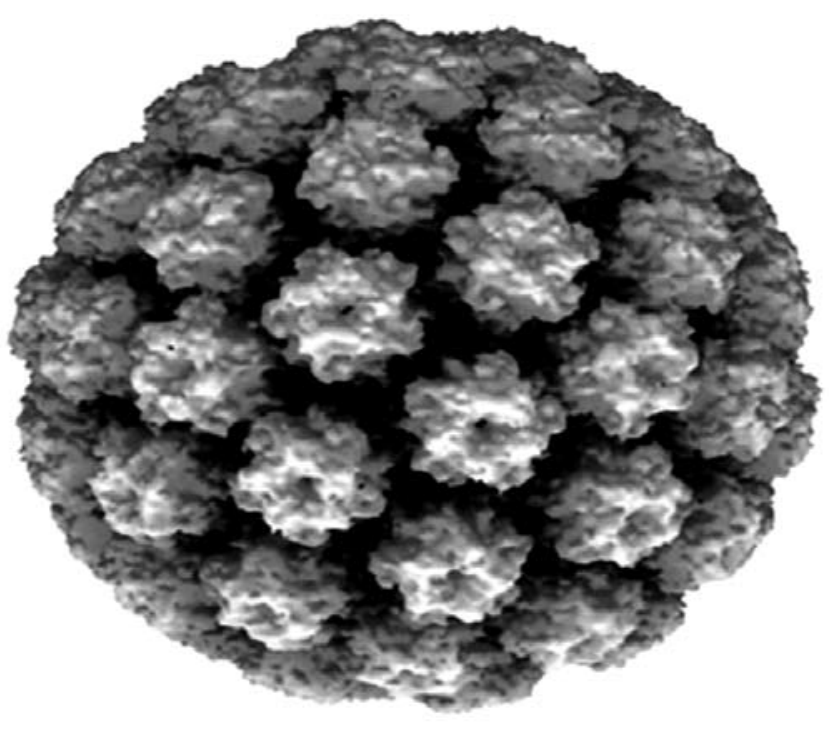

Фиг. 1. Модел на папиломен вирус

Освен това HPV се разделя на различни типове в зависимост от хомоложността на генетичния код на вируса. Досега са известни около 100 различни типа HPV. Ако отделните HPV-типове се групират въз основа на тяхната ДНК хомоложност, се получават групи от тясно свързани типове, които показват както еднакво тъканно предпочитание, така и подобни клинични прояви. Т.напр. типове 6 и 11 причиняват рецидивиращата респираторна папиломатоза, а в над $90 \%$ от случаите се доказват и при гениталните кондиломи. Типове 16 и 18 , а донякъде и типове 31,33 и 35 , се доказват при карцинома на маточната шийка, на дебелото черво и на дихателните органи. Така се оформят две големи групи HPV-типове - с нисък малигнен потенциал (типове 6 и 11) и с висок малигнен потенциал (типове 16, 18, 31, 33 и 35). При нискорисковите типове (HPV-6 и 11) HPV-геномът съществува като отделна част от клетъчното ядро на приемника, докато при високорисковите типове той е типично интегриран в клетьчната ДНК на хазяина. Тази интеграция е белег за малигнена трансформация на папиломните лезии.

Отделни типове HPV могат да се свържат и с тежестта и клиничното протичане на РРП. Деца, при които се доказва HPV тип 11, показват потежко протичане на заболяването, с ранна обструкция на дихателните пьтища и по-често се нуждаят от трахеотомия ${ }^{2}$, макар че други автори не споделят това мнение ${ }^{3}$.

Диагностицирането на различните папиломни лезии и определянето на вида на папиломния вирус се извършва посредством редица лабораторни методи:
Цитологичната диагностика се основава на техниката за фиксиране и оцветяване на клетъчни препарати (цитонамазка), описана от Papanicolau. Характерен цитологичен белег при HPV инфекцията е наличието на койлоцити и дискератоцити. Този метод намира най-широко приложение в гинекологията.

Хистологичното изследване се счита за "златен стандарт" при потвърждаване на диагнозата на HPV-асоциираните заболявания (Bonnez, 2002) ${ }^{4}$.

Имунохистохимични методи. Денатурацията на вирионите води до освобождаване на общ за всички папиломни вируси антиген (родовоспецифичен антиген). Антителата спрямо този антиген се използват за имунохистологична диагностика на HPV-инфекциите. Чувствителността на теста е ограничена и варира значително. Т. напр. общият папилома-вирусен антиген се установява в $68 \%$ от обикновените брадавици, в около $50 \%$ от ларингеалните папиломи и в $40 \%$ от лезиите на маточната шийка.

Молекулярни методи. Това са съвременни методи за откриване, идентифициране и анализ на НРвирусите. Тук спадат:

Хибридизационни методи. В основата им лежи разработеният от Е. Southern (1975) тест. При него екстрахираната от клетката ДНК се обработва с подходящи ензими, които накъсват ДНК на характерни фрагменти. Последните се разделят електрофоретично върху гел, след което се прехвърлят върху найлонова мембрана. Накрая се визуализират след специфична хибридизация с нуклеиново-киселинна сонда, маркирана с изотоп или ензим.

Амплификационни методи (Polymerase chain reaction). Принципът на метода се състои в ензимното in vitro намножаване (амплификация) на специфични фрагменти от вирусната нуклеинова киселина. Това се постига чрез използване на двойка специфични олигонуклеотидни “зародиши” (праймери ), които се прикрепват към уникални консервативни участьци на двете нуклеотидни вериги. Чрез последователно денатуриране на нуклеиновите киселини се постига милион-кратно увеличаване на желаните фрагменти.

Секвенционни техники. Представляват точното определяне на линейната нуклеотидна последователност в определен фрагмент или цял геном. Това дава широки възможности за определяне на вътретиповите варианти на даден HPV-вид, някои от които са с по-голям, а други - с по-малък онкогенен потенциал. 
Секвенционният анализ дава точна информация, но е скъп и трудно приложим за скрининг на голям брой проби.

Рецидивиращата респираторна папиломатоза е непредсказуемо по своя ход заболяване. Макар и с изяснена в голяма степен етиология, то все още е

\section{Литература:}

1. Shope R. Infectious papillomatosis of rabbits. J Exp Med 1933; 58: 607-624

2. Rimell FL, Shoemaker DL, Pou AM, Jordan JA, Post JC, Ehrlich GD. Pediatric respiratory papillomatosis: prognostic role of viral typing and cofactors. Laryngoscope 1997; 107: 915-18

3. Penaloza M, Montoya H, Flores SE, Fierro FJ, Penaloza JM, Sanches J. Molecular identification of 7 human papillomavirus types in recurrent недобре проучено и изисква много добра осведоменост от страна на цялата медицинска общественост и по-специално на оториноларинголозите, така че наличните терапевтични възможности да бъдат оптимално приложени при всеки отделен пациент.

respiratory papillomatosis. Arch Otolaryngol Head Neck Surg 2000; 126: 1119-23

4. Bonnez W. Papillomavirus. In: Clinical Virology. Ed Richman DD, Whitely RJ, Hayden FG, 2nd ed., Washington DC: ASM Press: 2002: $557-597$

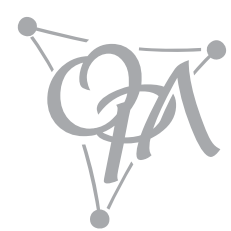

